\title{
KINETIC MODELLING OF a-C:H THIN FILM CHEMICAL VAPOUR DEPOSITION ON Si SUBSTRATE
}

\author{
A. Ibenskas ${ }^{a}$, A. Galdikas ${ }^{a, b}$, and A. Grigonis ${ }^{a}$ \\ ${ }^{a}$ Physics Department, Kaunas University of Technology, Studentu 50, LT-51368 Kaunas, Lithuania \\ E-mail: andiben@merkys.ktu.lt \\ b Department of Physics, Mathematics, and Biophysics, Kaunas University of Medicine, Eiveniu 4, LT-50166 Kaunas,
} Lithuania

Received 12 January 2007; revised 21 March 2007

\begin{abstract}
We simulated plasma enhanced chemical vapour deposition (CVD) of amorphous hydrogenated carbon (a-C:H) films on c-Si substrate using our new reaction rate model. Dependences of film deposition rate and mass density on the flux of atomic hydrogen were calculated for various $\mathrm{CH}_{3}$ fluxes and various ion energies. The calculated curves agree qualitatively with experimental results. Film deposition rate, as a function of hydrogen flux, has a maximum, which could be explained by (i) stabilization of dangling bond (DB) concentration on the surface and (ii) increased etching at high hydrogen fluxes. The results of simulation and experiments do not indicate any significant effect of ion energy variation on hydrogen content in the film. Detailed analysis of calculated dependences of $s p^{3} / s p^{2}$ ratio and hydrogen content on ion energy has revealed some interesting facts. First, the main mechanism of $s p^{3}$ bond formation is adsorption of $\mathrm{CH}_{3}$ on the surface. Also, as expected, the content of $s p^{3}$ declines at higher ion energies due to graphitization.
\end{abstract}

Keywords: kinetic model, reaction rate equations, amorphous hydrogenated carbon, ion energy

PACS: $81.05 . U w, 81.15 . G h, 82.20 .-w$

\section{Introduction}

Diamond-like amorphous carbon (DLC) thin films have attracted a great interest during the last decade [1-5]. Their superb properties made them desirable materials in technological and industrial applications such as protective coatings for cutting, drilling, and grinding tools, car parts, magnetic storage disks, optical windows. Some promising areas are biomedical coatings, thin film transistors (TFT), and microelectromechanical devices (MEMS). DLCs have very high mechanical hardness, high elastic modulus, low surface roughness, high wear resistance, large thermal conductivity, chemical inertness, and biocompatibility.

The structure and properties of a-C:H films depend on deposition technique, parameters, and substrate [1,6-9], so it is very important to understand deposition processes. Subplantation model claims that tetrahedral bonding appears as a result of high compressive stress $[2-4,10]$ or metastable increment in local density $[1,9]$, generated by low energy $(50-300 \mathrm{eV})$ ion implantation. In CVD, $s p^{3}$ bonded phase is also formed by adsorption of hydrocarbon radicals on the surface [6,11-13].
The content of $s p^{3}$ also increases due to preferential erosion (etching) of $s p^{2}$ sites with hydrogen [7]. $s p^{3}$-to-s $s p^{2}$ transition proceeds mostly via relaxation in thermal spikes [1] and, slightly, through chemical sputtering [7].

Reaction rate equation models provide ability to track film composition kinetics in time and reveal the effect of experimental parameters. In the current work, we simulate CVD of a-C:H film using a new kinetic model.

\section{Model}

Among particles involved in a-C:H film deposition, we also include activated particles that have a dangling bond (DB) and we mark them with asterisk $\left(^{*}\right)$, e.g. activated $\mathrm{Si}$ atom hereafter is marked as $\mathrm{Si}^{*}$. We will distinguish between two major types of carbon atoms: $s p^{2}$ - and $s p^{3}$-hybridized, or $\mathrm{C}_{s p^{2}}$ and $\mathrm{C}_{s p^{3}}$, respectively. Carbon atoms may have DBs. Such atoms will be marked as $\mathrm{C}_{s p^{2}}^{*}$ or $\mathrm{C}_{s p^{3}}^{*}$. Moreover, any carbon atom can make bonds with one, two, or even three hydrogen atoms at a time. Such carbon atoms are called 
Table 1. Types of particles $i$ involved in reactions and their relative concentrations $c_{i}^{(k)}$.

\begin{tabular}{cccccccccccccccc}
\hline 1 & 2 & 3 & 4 & 5 & 6 & 7 & 8 & 9 & 10 & 11 & 12 & 13 & 14 & 15 \\
\hline $\mathrm{Si}$ & $\mathrm{Si}^{*}$ & $\mathrm{C}_{s p^{2}}$ & $\mathrm{C}_{s p^{2}}^{*}$ & $\mathrm{C}_{s p^{2}} \mathrm{H}$ & $\mathrm{C}_{s p^{2} \mathrm{H}^{*}}$ & $\mathrm{C}_{s p^{2}} \mathrm{H}_{2}$ & $\mathrm{C}_{s p^{3}}$ & $\mathrm{C}_{s p^{3}}^{*}$ & $\mathrm{C}_{s p^{3}} \mathrm{H}$ & $\mathrm{C}_{s p^{3}} \mathrm{H}^{*}$ & $\mathrm{C}_{s p^{3}} \mathrm{H}_{2}$ & $\mathrm{C}_{s p^{3}} \mathrm{H}_{2}{ }^{*}$ & $\mathrm{C}_{s p^{3}} \mathrm{H}_{3}$ & $\mathrm{H}$ \\
\hline$c_{1}^{(k)}$ & $c_{2}^{(k)}$ & $c_{3}^{(k)}$ & $c_{4}^{(k)}$ & $c_{5}^{(k)}$ & $c_{6}^{(k)}$ & $c_{7}^{(k)}$ & $c_{8}^{(k)}$ & $c_{9}^{(k)}$ & $c_{10}^{(k)}$ & $c_{11}^{(k)}$ & $c_{12}^{(k)}$ & $c_{13}^{(k)}$ & $c_{14}^{(k)}$ & $c_{15}^{(k)}$ \\
\hline
\end{tabular}

mono-, di-, or trihydrogenated, respectively. Therefore, in case of $s p^{3}$ bonding, we may have $\mathrm{C}_{s p^{3}} \mathrm{H}, \mathrm{C}_{s p^{3}} \mathrm{H}_{2}$, and $\mathrm{C}_{s p^{3}} \mathrm{H}_{3}$. Note that $s p^{2}$-bonded $\mathrm{C}$ atoms cannot be trihydrogenated. Some mono- and dihydrogenated $\mathrm{C}$ atoms have DBs. To refer to them, we will use notations $\mathrm{C}_{s p^{3}} \mathrm{H}^{*}$ and $\mathrm{C}_{s p^{3}} \mathrm{H}_{2}{ }^{*}$ in case of $s p^{3}$ bonding, or $\mathrm{C}_{s p^{2}} \mathrm{H}^{*}$ in case of $s p^{2}$ bonding. Non-bonded hydrogen atoms in the film are simply marked as H. Particle types are numbered from 1 to 15 (Table 1 ). Relative particle concentrations $c_{i}^{(k)}(i=1, \ldots, 15)$ in $k$ th monolayer with respect to the total atom concentration in $k$ th monolayer are used throughout this work. A relative flux $i_{i}\left(\mathrm{~s}^{-1}\right)$ of $i$ th type particles arriving to the very surface, with respect to the total surface atom concentration $n_{\mathrm{S}}\left(n_{\mathrm{S}}=2.75 \cdot 10^{15} \mathrm{~cm}^{-2} \mathrm{~s}^{-1}\right.$ in this work), is obtained as $i_{i}=I_{i} / n_{\mathrm{S}}$ where $I_{i}$ is an absolute flux $\left(\mathrm{cm}^{-2} \mathrm{~s}^{-1}\right)$ of $i$ th type particles. We consider that the only incident particles are $\mathrm{C}^{+}$ions, $\mathrm{CH}_{3}$ radicals, $\mathrm{H}$ radicals, and $\mathrm{H}^{+}$ions. Their relative fluxes are denoted as $i_{\mathrm{C}^{+}}, i_{\mathrm{R}}, i_{\mathrm{H}^{\prime}}$, and $i_{\mathrm{H}^{+}}$, respectively. The film is modelled as a stack of monolayers. A relative flux of $i$ th type particles that penetrates as deep as $k$ th monolayer is defined by

$$
i_{i}^{(k)}=i_{i}\left[\Phi\left(\frac{k d-R_{\mathrm{p}}}{\Delta R_{\mathrm{p}}}\right)-\Phi\left(\frac{(k-1) d-R_{\mathrm{p}}}{\Delta R_{\mathrm{p}}}\right)\right],
$$

where $i_{i}^{(k)}$ stands for $i_{\mathrm{C}^{+}}^{(k)}, i_{\mathrm{H}^{\prime}}^{(k)}$, or $i_{\mathrm{H}^{+}}^{(k)}$. Here, $k$ is a monolayer number (starting with the surface, $k=$ $1, \ldots, n_{\mathrm{sl}}$, where $n_{\mathrm{sl}}$ is a number of monolayers), $d \approx$ $3 \AA$ is a mean monolayer thickness, $R_{\mathrm{p}}$ is an average penetration depth of $i$ th type particle $(\AA), \Delta R_{\mathrm{p}}$ is a standard deviation $(\AA) . \Phi\left(x, R_{\mathrm{p}}, \Delta R_{\mathrm{p}}\right)$ is a cumulative function of normal (Gaussian) distribution. We also introduce a total hydrogen flux incident to the surface and a total hydrogen flux penetrating into the $k$ th monolayer, respectively, $i_{\mathrm{H}}=i_{\mathrm{H}^{\prime}}+i_{\mathrm{H}^{+}}$and $i_{\mathrm{H}}^{(k)}=i_{\mathrm{H}^{\prime}}^{(k)}+i_{\mathrm{H}^{+}}^{(k)}$.

\subsection{Graphite-to-diamond transition due to ion bombardment induced stress in subsurface region}

This phenomenon is well covered by many papers $[1-4,10,14]$. We assume that the pressure is low enough so that ions are monoenergetic and their mean energy $E$ is proportional to the bias voltage $V_{\mathrm{b}}$, i.e. $E=E_{\mathrm{p}}-e V_{\mathrm{b}}$ where $E_{\mathrm{p}}$ is a mean ion energy in plasma, $E_{\mathrm{p}} \approx 15 \mathrm{eV}$ [6]. We consider only $\mathrm{CH}_{3}{ }^{+}$ ions because their contribution to film deposition is the most important. The majority of $\mathrm{CH}_{3}+$ ions with energy above $\sim 40 \mathrm{eV}$ decay into separate atoms on impact with the surface [1] so we take into account only surface bombardment by $\mathrm{C}^{+}$ions with energy $E$.

Graphite transformation to diamond in subsurface region can be defined by modified Davis [3] formula

$$
z_{0}=B \frac{\left(\frac{E}{E_{\text {crit }}}\right)^{1 / 2}}{\left(\frac{V}{i_{\mathrm{C}+}}\right)+0.016 \rho\left(\frac{E}{E_{0}}\right)^{5 / 3}},
$$

where $B$ is a constant, $V$ is film deposition rate, $i_{\mathrm{C}^{+}}$ is $\mathrm{C}^{+}$ion relative flux, $\rho$ is a material dependent parameter of order 1 (unity), $E_{\text {crit }}$ is a threshold energy for implantation $(32 \mathrm{eV}), E_{0}$ is $\mathrm{C}$ atom displacement energy $(\sim 3 \mathrm{eV})$. We assume that only inactivated particles can participate in the structural transition because their concentration is much higher then that of activated particles. The following changes in carbon atom hybridization may occur:

1. $s p^{2}$ bonded carbon atoms become $s p^{3}$ bonded carbon atoms, $\mathrm{C}_{s p^{2}} \rightarrow \mathrm{C}_{s p^{3}}$. The concentration of $s p^{2}$ bonded carbon atoms decreases, and the concentration of $s p^{3}$ bonded carbon atoms increases as

$$
\left(\frac{\mathrm{d} c_{i}^{(k)}}{\mathrm{d} t}\right)_{s p^{2}}=-z^{(k)} c_{i}^{(k)},\left(\frac{\mathrm{d} c_{j}^{(k)}}{\mathrm{d} t}\right)_{s p^{3}}=z^{(k)} c_{i}^{(k)}
$$

where $i=3$ (corresponds to particle type $\mathrm{C}_{s p^{2}}$ ) and $j=8$ (corresponds to particle type $\mathrm{C}_{s p^{3}}$ ). Hydrogenated carbon atoms can also change their bonding type;

2. $\mathrm{C}_{s p^{2}} \mathrm{H} \rightarrow \mathrm{C}_{s p^{3}} \mathrm{H}$, a process, which is described by rate equations similar to Eq. (3) but with $i=5$ and $j=10$ referring to particle types $\mathrm{C}_{s p^{2}} \mathrm{H}$ and $\mathrm{C}_{s p^{3}} \mathrm{H}$;

3. $\mathrm{C}_{s p^{2}} \mathrm{H}_{2} \rightarrow \mathrm{C}_{s p^{3}} \mathrm{H}_{2}$, consequently equations similar to Eq. (3) are used again, with $i=7\left(\mathrm{C}_{s p^{2}} \mathrm{H}_{2}\right)$ and $j=12\left(\mathrm{C}_{s p^{3}} \mathrm{H}_{2}\right)$. 
Here $z^{(k)}=z_{0} i_{\mathrm{C}+}^{(k)}$ is a frequency probability $\left(\mathrm{s}^{-1}\right)$ that the bonding of carbon atom in $k$ th monolayer will change from $s p^{2}$ to $s p^{3}$.

\subsection{Diamond-to-graphite transformation \\ (graphitization) in the bulk of the film}

Upon irradiation with high energy ions, a large fraction of ion energy is dissipated as phonons (heat) at a small volume or along ion trajectory, which is called thermal spike. Due to high temperature at thermal spikes, atoms diffuse back to the surface, and diamond phase relaxes to stable graphite phase $[1,3]$. Therefore, $s p^{3}$ content in the film decreases and $s p^{2}$ content increases. If we take into account that some $\mathrm{C}$ atoms in the film are bonded to $\mathrm{H}$ atoms, then graphitization can be depicted by following plain equations:

(i) $\mathrm{C}_{s p^{3}} \rightarrow \mathrm{C}_{s p^{2}}$,

(ii) $\mathrm{C}_{s p^{3}} \mathrm{H} \rightarrow \mathrm{C}_{s p^{2}} \mathrm{H}$,

(iii) $\mathrm{C}_{s p^{3}} \mathrm{H}_{2} \rightarrow \mathrm{C}_{s p^{2}} \mathrm{H}_{2}$.

We will use one general form of equations for graphitization:

$$
\begin{gathered}
\left(\frac{\mathrm{d} c_{i}^{(k)}}{\mathrm{d} t}\right)_{s p^{3}}=-z_{2}^{(k)} c_{i}^{(k)},\left(\frac{\mathrm{d} c_{j}^{(k)}}{\mathrm{d} t}\right)_{s p^{2}}=z_{2}^{(k)} c_{i}^{(k)}, \\
z_{02}=\lambda \cdot 0.016 \rho\left(\frac{E}{E_{0}}\right)^{5 / 3}
\end{gathered}
$$

where $z_{02}$ is a quantity related to relaxation rate, $\lambda$ is a material dependent modelling parameter, $z_{2}^{(k)}=$ $z_{02} i_{\mathrm{C}^{+}}^{(k)}$ is a frequency probability that carbon atom in $k$ th monolayer, either bonded or not bonded to $\mathrm{H}$ atom, will change its hybridization from $s p^{3}$ to $s p^{2}$.

Indices $i$ and $j$ in Eq. (4) differ for the three types of graphitization:

(i) $i=8\left(\mathrm{C}_{s p^{3}}\right), j=3\left(\mathrm{C}_{s p^{2}}\right)$,

(ii) $i=10\left(\mathrm{C}_{s p^{3}} \mathrm{H}\right), j=5\left(\mathrm{C}_{s p^{2}} \mathrm{H}\right)$,

(iii) $i=12\left(\mathrm{C}_{s p^{3}} \mathrm{H}_{2}\right), j=7\left(\mathrm{C}_{s p^{2}} \mathrm{H}_{2}\right)$.

\subsection{Activation of Si atoms on the surface and adsorption of $\mathrm{CH}_{3}$ on activated Si atoms} by

We assume growth on Si surface is carried largely

1. Si activation by ion bombardment [15], $\mathrm{Si} \rightarrow \mathrm{Si}^{*}$. Concentration of inactivated $\mathrm{Si}$ atoms decreases, and the concentration of activated $\mathrm{Si}$ atoms increases as following:

$$
\begin{aligned}
& \left(\frac{\mathrm{d} c_{1}^{(1)}}{\mathrm{d} t}\right)_{\mathrm{Si}}=-G_{1} c_{1}^{(1)} i_{\mathrm{C}^{+}}, \\
& \left(\frac{\mathrm{d} c_{2}^{(1)}}{\mathrm{d} t}\right)_{\mathrm{Si}^{*}}=G_{1} c_{1}^{(1)} i_{\mathrm{C}^{+}},
\end{aligned}
$$

where $G_{1}$ is a frequency probability of activation, dependent on incident ion energy.

2. Adsorption of hydrocarbons $\left(\mathrm{CH}_{3}\right)$ on activated $\mathrm{Si}$ atoms with adsorption probability $k_{\mathrm{R}}, \mathrm{Si}^{*}+$ $\mathrm{CH}_{3} \rightarrow \mathrm{Si}-\mathrm{CH}_{3}$. Concentration of activated $\mathrm{Si}$ atoms $\left(\mathrm{Si}^{*}\right)$ decreases and the concentration of $s p^{3}$ bonded trihydrogenated carbon atoms $\left(\mathrm{C}_{s p^{3}} \mathrm{H}_{3}\right)$ increases, as well as the concentration of $\mathrm{H}$ atoms on the surface:

$$
\begin{aligned}
& \left(\frac{\mathrm{d} c_{2}^{(1)}}{\mathrm{d} t}\right)_{\mathrm{Si}^{*}}=-k_{\mathrm{R}} c_{2}^{(1)} i_{\mathrm{R}} \\
& \left(\frac{\mathrm{d} c_{14}^{(1)}}{\mathrm{d} t}\right)_{s p^{3} \mathrm{H}_{3}}=k_{\mathrm{R}} c_{2}^{(1)} i_{\mathrm{R}} .
\end{aligned}
$$

Moreover, we assume that $\mathrm{C}$ atom of adsorbed $\mathrm{CH}_{3}$ radical covers the primary, activated $\mathrm{C}$ atom on the surface, and the three $\mathrm{H}$ atoms of adsorbed $\mathrm{CH}_{3}$ cover any other three surface atoms. Thus, the concentration of every type surface particles decreases by

$$
\begin{aligned}
& \left(\frac{\mathrm{d} c_{15}^{(1)}}{\mathrm{d} t}\right)_{\mathrm{H}}=3 k_{\mathrm{R}} c_{2}^{(1)} i_{\mathrm{R}} \\
& \left(\frac{\mathrm{d} c_{i}^{(1)}}{\mathrm{d} t}\right)_{i}=-3 k_{\mathrm{R}} c_{2}^{(1)} i_{\mathrm{R}} c_{i}^{(1)}(i=1, \ldots, 15) .
\end{aligned}
$$

\subsection{Abstraction of $H$ atoms from the surface and the} bulk by incoming $\mathrm{H}$ atoms and $\mathrm{H}^{+}$ions

In order to describe this process, we introduce an abstraction coeffcient, $w_{\mathrm{HH}}$. Incident $\mathrm{H}$ radicals abstract surface and bulk $\mathrm{H}$ atoms that are bonded to $s p^{2}$ and $s p^{3}$ sites $\mathrm{C}_{s p^{2}} \mathrm{H}, \mathrm{C}_{s p^{2}} \mathrm{H}_{2}, \mathrm{C}_{s p^{3}} \mathrm{H}, \mathrm{C}_{s p^{3}} \mathrm{H}_{2}$, and $\mathrm{C}_{s p^{3}} \mathrm{H}_{3}$ [1,5-8]. The concentration of activated carbon atoms, $\mathrm{C}_{s p^{2}}^{*}, \mathrm{C}_{s p^{2}} \mathrm{H}^{*}, \mathrm{C}_{s p^{3}}^{*}, \mathrm{C}_{s p^{3}} \mathrm{H}^{*}$, and $\mathrm{C}_{s p^{3}} \mathrm{H}_{2}{ }^{*}$, increases.

(1) (film) $-\mathrm{C}_{s p^{2}} \mathrm{H}+\mathrm{H} \rightarrow$ (film) $-\mathrm{C}_{s p^{2}}^{*}+\mathrm{H}_{2}$,

(2) (film) $-\mathrm{C}_{s p^{2}} \mathrm{H}_{2}+\mathrm{H} \rightarrow$ (film) $-\mathrm{C}_{s p^{2}} \mathrm{H}^{*}+\mathrm{H}_{2}$,

(3) (film) $-\mathrm{C}_{s p^{3}} \mathrm{H}+\mathrm{H} \rightarrow$ (film) $-\mathrm{C}_{s p^{3}}^{*}+\mathrm{H}_{2}$,

(4) (film) $-\mathrm{C}_{s p^{3}} \mathrm{H}_{2}+\mathrm{H} \rightarrow$ (film) $-\mathrm{C}_{s p^{3}} \mathrm{H}^{*}+\mathrm{H}_{2}$, 
(5) (film) $-\mathrm{C}_{s p^{3}} \mathrm{H}_{3}+\mathrm{H} \rightarrow$ (film) $-\mathrm{C}_{s p^{3}} \mathrm{H}_{2}{ }^{*}+\mathrm{H}_{2}$,

where a particle bonded to any unspecified particle in the bulk of the film is marked as '(film)-particle'. The variation of atom concentrations is estimated as

$$
\begin{aligned}
& \left(\frac{\mathrm{d} c_{j}^{(1)}}{\mathrm{d} t}\right)_{j}=-w_{\mathrm{HH}} c_{j}^{(k)} i_{\mathrm{H}}^{(k)}, \\
& \left(\frac{\mathrm{d} c_{j}^{(1)}}{\mathrm{d} t}\right)_{j}=w_{\mathrm{HH}} c_{j}^{(k)} i_{\mathrm{H}}^{(k)},
\end{aligned}
$$

where $j$ and $i$ are conjugate indices, $j=5,7,10$, 12, 14 (correspond to particles $\mathrm{C}_{s p^{2}} \mathrm{H}, \mathrm{C}_{s p^{2}} \mathrm{H}_{2}, \mathrm{C}_{s p^{3}} \mathrm{H}$, $\mathrm{C}_{s p^{3}} \mathrm{H}_{2}, \mathrm{C}_{s p^{3}} \mathrm{H}_{3}$ ), and $i=4,6,9,11,13$ (particles $\mathrm{C}_{s p^{2}}^{*}$, $\left.\mathrm{C}_{s p^{2}} \mathrm{H}^{*}, \mathrm{C}_{s p^{3}}, \mathrm{C}_{s p^{3}} \mathrm{H}^{*}, \mathrm{C}_{s p^{3}} \mathrm{H}_{2}{ }^{*}\right)$; e. g., $j=7$ and $i=6$, $k=1, \ldots, n_{\mathrm{sl}}$. The total $\mathrm{H}$ concentration in $k$ th monolayer decreases:

$\left(\frac{\mathrm{d} c_{15}^{(1)}}{\mathrm{d} t}\right)_{\mathrm{H}}=-w_{\mathrm{HH}}\left(c_{5}^{(k)}+c_{7}^{(k)}+c_{10}^{(k)}+c_{12}^{(k)}+c_{14}^{(k)}\right) i_{\mathrm{H}}^{(k)}$.

\section{5. $\mathrm{CH}_{3}$ adsorption on activated carbon atoms}

$\mathrm{CH}_{3}$ radicals can easily adsorb on activated carbon atoms that have a dangling bond $[6,8,11,12]$, i.e. on $\mathrm{C}_{s p^{2}}^{*}, \mathrm{C}_{s p^{2}} \mathrm{H}^{*}, \mathrm{C}_{s p^{3}}^{*}, \mathrm{C}_{s p^{3}} \mathrm{H}^{*}$, and $\mathrm{C}_{s p^{3}} \mathrm{H}_{2}{ }^{*}$ :

(1) (surface) $-\mathrm{C}_{s p^{2}}^{*}+\mathrm{CH}_{3} \rightarrow($ surface $)-\mathrm{C}_{s p^{2}}-\mathrm{CH}_{3}$,

(2) (surface) $-\mathrm{C}_{s p^{2}} \mathrm{H}^{*}+\mathrm{CH}_{3} \rightarrow$ (surface) $-\mathrm{C}_{s p^{2}} \mathrm{H}-$ $\mathrm{CH}_{3}$,

(3) (surface) $-\mathrm{C}_{s p^{3}}^{*}+\mathrm{CH}_{3} \rightarrow$ (surface) $-\mathrm{C}_{s p^{3}}-\mathrm{CH}_{3}$,

(4) (surface) $-\mathrm{C}_{s p^{3}} \mathrm{H}^{*}+\mathrm{CH}_{3} \rightarrow$ (surface) $-\mathrm{C}_{s p^{3}} \mathrm{H}-$ $\mathrm{CH}_{3}$,

(5) (surface) $-\mathrm{C}_{s p^{3}} \mathrm{H}_{2}{ }^{*}+\mathrm{CH}_{3} \rightarrow\left(\right.$ surface) $-\mathrm{C}_{s p}{ }^{3} \mathrm{H}_{2}$ $-\mathrm{CH}_{3}$.

The concentration of activated carbon atoms decreases, as can bee seen in equation

$$
\left(\frac{\mathrm{d} c_{i}^{(1)}}{\mathrm{d} t}\right)_{i}=-k_{\mathrm{R}} i_{\mathrm{R}} c_{i}^{(1)}=-K_{\mathrm{R}} c_{i}^{(1)}
$$

where $i=4,6,9,11,13$, or particles $\mathrm{C}_{s p^{2}}^{*}, \mathrm{C}_{s p^{2}} \mathrm{H}^{*}$, $\mathrm{C}_{s p^{3}}, \mathrm{C}_{s p^{3}} \mathrm{H}^{*}, \mathrm{C}_{s p^{3}} \mathrm{H}_{2}{ }^{*}$, respectively, $k_{\mathrm{R}}$ is a sticking probability of $\mathrm{CH}_{3}, K_{\mathrm{R}}$ is a frequency probability $\left(\mathrm{s}^{-1}\right)$ of $\mathrm{CH}_{3}$ adsorption. The concentration of $s p^{3}$ bonded, trihydrogenated carbon atoms and the concentration of $\mathrm{H}$ atoms on the surface increase, see Eq. (12). C atom of adsorbed $\mathrm{CH}_{3}$ radical covers the surface $\mathrm{C}$ atom, and three $\mathrm{H}$ atoms of $\mathrm{CH}_{3}$ radical cover three other surface atoms that can be of any type. This process is described by Eq. (13) in the same manner as adsorption on $\mathrm{Si}^{*}$.

$$
\begin{aligned}
\left(\frac{\mathrm{d} c_{14}^{(1)}}{\mathrm{d} t}\right)_{s p^{3} \mathrm{H}_{3}} & =C_{\mathrm{R}},\left(\frac{\mathrm{d} c_{15}^{(1)}}{\mathrm{d} t}\right)_{\mathrm{H}}=3 C_{\mathrm{R}}, \\
C_{\mathrm{R}} & =K_{\mathrm{R}} \sum_{j=4,6,9,11,13} c_{j}^{(1)}, \\
\left(\frac{\mathrm{d} c_{m}^{(1)}}{\mathrm{d} t}\right)_{m} & =-3 C_{\mathrm{R}} c_{m}^{(1)} \quad(m=1 \ldots 15) .
\end{aligned}
$$

\subsection{Re-saturation of DBs by incoming $H$ atoms and $H^{+}$ions on the surface and in the bulk}

Incoming neutral $\mathrm{H}$ atoms and $\mathrm{H}^{+}$ions usually stick to carbon atoms that have dangling bonds [1,6$9,12,16]$, e.g. $\mathrm{C}_{s p^{2}}^{*}, \mathrm{C}_{s p^{2}} \mathrm{H}^{*}, \mathrm{C}_{s p^{3}}^{*}, \mathrm{C}_{s p^{3}} \mathrm{H}^{*}$, and $\mathrm{C}_{s p^{3}} \mathrm{H}_{2}{ }^{*}$. These surface particles are deactivated and converted into $\mathrm{C}_{s p^{2}} \mathrm{H}, \mathrm{C}_{s p^{2}} \mathrm{H}_{2}, \mathrm{C}_{s p^{3}} \mathrm{H}, \mathrm{C}_{s p^{3}} \mathrm{H}_{2}$, and $\mathrm{C}_{s p} \mathrm{H}_{3}$, respectively. This process occurs both on the surface and in the bulk of the film:

(1) (film) $-\mathrm{C}_{s p^{2}}^{*}+\mathrm{H} \rightarrow$ (film) $-\mathrm{C}_{s p^{2}} \mathrm{H}$,

(2) (film) $-\mathrm{C}_{s p^{2}} \mathrm{H}^{*}+\mathrm{H} \rightarrow$ (film) $-\mathrm{C}_{s p^{2}} \mathrm{H}_{2}$,

(3) (film) $-\mathrm{C}_{s p^{3}}^{*}+\mathrm{H} \rightarrow$ (film) $-\mathrm{C}_{s p^{3}} \mathrm{H}$,

(4) (film) $-\mathrm{C}_{s p^{3}} \mathrm{H}^{*}+\mathrm{H} \rightarrow$ (film) $-\mathrm{C}_{s p^{3}} \mathrm{H}_{2}$,

(5) (film) $-\mathrm{C}_{s p^{3}} \mathrm{H}_{2}{ }^{*}+\mathrm{H} \rightarrow$ (film) $-\mathrm{C}_{s p^{3}} \mathrm{H}_{3}$.

Reaction rate equations for $\mathrm{H}$ adsorption on dangling bonds with adsorption probability $k_{\mathrm{H}}$ are the following:

$\left(\frac{\mathrm{d} c_{i}^{(k)}}{\mathrm{d} t}\right)_{i}=-k_{\mathrm{H}} c_{i}^{(k)} i_{\mathrm{H}}^{(k)},\left(\frac{\mathrm{d} c_{J}^{(k)}}{\mathrm{d} t}\right)_{j}=-k_{\mathrm{H}} c_{i}^{(k)} i_{\mathrm{H}}^{(k)}$,

$$
\left(\frac{\mathrm{d} c_{15}^{(1)}}{\mathrm{d} t}\right)_{\mathrm{H}}=\sum_{i} k_{\mathrm{H}} c_{i}^{(1)} i_{\mathrm{H}}
$$

$$
\left(\frac{\mathrm{d} c_{m}^{(1)}}{\mathrm{d} t}\right)_{m}=-\sum_{i} k_{\mathrm{H}} c_{i}^{(1)} i_{\mathrm{H}} c_{m}^{(1)}
$$

where $i$ and $j$ are conjugate indices, $i=4,6,9,11$, 13 (activated particles $\mathrm{C}_{s p^{2}}^{*}, \mathrm{C}_{s p^{2}} \mathrm{H}^{*}, \mathrm{C}_{s p^{3}}^{*}, \mathrm{C}_{s p^{3}} \mathrm{H}^{*}$, $\mathrm{C}_{s p^{3}} \mathrm{H}_{2}{ }^{*}$, respectively), and $j=5,7,10,12,14\left(\mathrm{C}_{s p^{2}} \mathrm{H}\right.$, $\left.\mathrm{C}_{s p^{2}} \mathrm{H}_{2}, \mathrm{C}_{s p^{3}} \mathrm{H}, \mathrm{C}_{s p^{3}} \mathrm{H}_{2}, \mathrm{C}_{s p^{3}} \mathrm{H}_{3}\right), m=1, \ldots, 15$. Incident $\mathrm{H}$ atoms make bonds with activated carbon atoms on the surface, and $\mathrm{H}$ concentration increases. However, incident $\mathrm{H}$ atoms do not cover these particular carbon atoms. Instead, they cover the nearby particles. This leads to decrease in surface concentration of all particles, see Eq. (15). 


\subsection{Relaxation of activated particles}

Relaxation of activated particles takes place on the surface and in the bulk of the film. Activated particles $\mathrm{C}_{s p^{2}}^{*}, \mathrm{C}_{s p^{2}} \mathrm{H}^{*}, \mathrm{C}_{s p^{3}}^{*}, \mathrm{C}_{s p^{3}} \mathrm{H}^{*}$, and $\mathrm{C}_{s p^{3}} \mathrm{H}_{2}{ }^{*}$ can make bonds with other activated particles and become $\mathrm{C}_{s p^{2}}$, $\mathrm{C}_{s p^{2}} \mathrm{H}, \mathrm{C}_{s p^{3}}, \mathrm{C}_{s p^{3}} \mathrm{H}$, or $\mathrm{C}_{s p^{3}} \mathrm{H}_{2}[5,7,8]$, respectively:

(1) (film) $-\mathrm{C}_{s p^{2}}^{*} \rightarrow$ (film) $-\mathrm{C}_{s p^{2}}$,

(2) (film) $-\mathrm{C}_{s p^{2}} \mathrm{H}^{*} \rightarrow$ (film) $-\mathrm{C}_{s p^{2}} \mathrm{H}$,

(3) (film) $-\mathrm{C}_{s p^{3}}^{*} \rightarrow$ (film) $-\mathrm{C}_{s p^{3}}$,

(4) (film) $-\mathrm{C}_{s p^{3}} \mathrm{H}^{*} \rightarrow$ (film) $-\mathrm{C}_{s p}{ }^{3} \mathrm{H}$,

(5) (film) $-\mathrm{C}_{s p^{3}} \mathrm{H}_{2}{ }^{*} \rightarrow$ (film) $-\mathrm{C}_{s p^{3}} \mathrm{H}_{2}$.

Relaxation is described by reaction rate equations

$$
\left(\frac{\mathrm{d} c_{i}^{(k)}}{\mathrm{d} t}\right)_{i}=-F c_{i}^{(k)},\left(\frac{\mathrm{d} c_{j}^{(k)}}{\mathrm{d} t}\right)_{j}=F c_{i}^{(k)},
$$

where $i$ and $j$ are conjugate indices, $i=4,6,9,11$, $13\left(\mathrm{C}_{s p^{2}}^{*}, \mathrm{C}_{s p^{2}} \mathrm{H}^{*}, \mathrm{C}_{s p^{3}}^{*}, \mathrm{C}_{s p^{3}} \mathrm{H}^{*}\right.$, and $\mathrm{C}_{s p^{3}} \mathrm{H}_{2}{ }^{*}$, respectively), and $j=3,5,8,10,12\left(\mathrm{C}_{s p^{2}}, \mathrm{C}_{s p^{2}} \mathrm{H}\right.$, $\mathrm{C}_{s p^{3}}, \mathrm{C}_{s p^{3}} \mathrm{H}$, and $\left.\mathrm{C}_{s p^{3}} \mathrm{H}_{2}\right), F$ is a relaxation coefficient $\left(\mathrm{s}^{-1}\right)$. Relaxing carbon atoms may also change their hybridization from $s p^{3}$ to $s p^{2}$ :

(1) (film) $-\mathrm{C}_{s p^{3}}^{*} \rightarrow$ (film) $-\mathrm{C}_{s p^{2}}$,

(2) (film) $-\mathrm{C}_{s p^{3}} \mathrm{H}^{*} \rightarrow$ (film) $-\mathrm{C}_{s p^{2}} \mathrm{H}$.

Rate equations for relaxation with change of hybridization have exactly the same form as Eq. (16) but with coefficient $F_{2}$ instead of $F$, and $i=9$ or $11\left(\mathrm{C}_{s p^{3}}^{*}\right.$ or $\mathrm{C}_{s p^{3}} \mathrm{H}^{*}$, respectively), $j=3$ or $5\left(\mathrm{C}_{s p^{2}}\right.$ or $\mathrm{C}_{s p^{2}} \mathrm{H}$, respectively).

\section{8. $H$ atom displacement in the bulk of the film}

Hydrogen atom binding energy of a few $\mathrm{eV}$ in a-C:H films is much lower than for carbon atoms, so incident $\mathrm{C}^{+}$and $\mathrm{H}^{+}$ions can easily displace $\mathrm{H}$ atoms from $\mathrm{C}-$ $\mathrm{H}$ bonds. Displaced $\mathrm{H}$ atoms can recombine with each other to form $\mathrm{H}_{2}$ molecules, and these desorb from the film $[1,9]$. We assume that all displaced $\mathrm{H}$ atoms leave the film.

(1) (film) $-\mathrm{C}_{s p^{2}} \mathrm{H} \rightarrow$ (film) $-\mathrm{C}_{s p^{2}}^{*}$,

(2) (film) $-\mathrm{C}_{s p^{2}} \mathrm{H}_{2} \rightarrow$ (film) $-\mathrm{C}_{s p^{2}} \mathrm{H}^{*}$,

(3) (film) $-\mathrm{C}_{s p^{3}} \mathrm{H} \rightarrow$ (film) $-\mathrm{C}_{s p^{3}}^{*}$,

(4) (film) $-\mathrm{C}_{s p^{3}} \mathrm{H}_{2} \rightarrow$ (film) $-\mathrm{C}_{s p^{3}} \mathrm{H}^{*}$,

(5) (film) $-\mathrm{C}_{s p^{3}} \mathrm{H}_{3} \rightarrow$ (film) $-\mathrm{C}_{s p^{3}} \mathrm{H}_{2}{ }^{*}$.

We mark the frequency probability $\left(\mathrm{s}^{-1}\right)$ of $\mathrm{H}$ displacement in $k$ th monolayer by $\mathrm{C}^{+}$ion as $G_{\mathrm{H} 1}^{(k)}$, and
$\mathrm{H}$ displacement by $\mathrm{H}^{+}$ion as $G_{\mathrm{H} 2}^{(k)}$. These displacement coefficients are found with the SRIM (Stopping and Range of Ions in Matter) software [17]. The total frequency probability of $\mathrm{H}$ displacement, either by $\mathrm{C}^{+}$or $\mathrm{H}^{+}$, is $G_{\mathrm{H}}^{(k)}=G_{\mathrm{H} 1}^{(k)} i_{\mathrm{C}^{+}}^{(k)}+G_{\mathrm{H} 2}^{(k)} i_{\mathrm{H}^{+}}^{(k)}$. The activation of carbon atoms due to broken $\mathrm{C}-\mathrm{H}$ bonds and the decrease in $\mathrm{H}$ concentration can be estimated by equations

$$
\begin{gathered}
\left(\frac{\mathrm{d} c_{j}^{(k)}}{\mathrm{d} t}\right)_{j}=-G_{\mathrm{H}}^{(k)} c_{j}^{(k)},\left(\frac{\mathrm{d} c_{i}^{(k)}}{\mathrm{d} t}\right)_{i}=G_{\mathrm{H}}^{(k)} c_{j}^{(k)}, \\
\left(\frac{\mathrm{d} c_{15}^{(k)}}{\mathrm{d} t}\right)_{\mathrm{H}}=-G_{\mathrm{H}}^{(k)}\left(c_{5}^{(k)}+c_{7}^{(k)}+c_{10}^{(k)}+c_{12}^{(k)}+c_{14}^{(k)}\right),
\end{gathered}
$$

where $j$ and $i$ are conjugate indices, see Sec. 2.4; $k=$ $2, \ldots, n_{\mathrm{sl}}$.

\subsection{Physical sputtering of $H$ atoms on the surface}

Hydrogen atoms are sputtered from the surface by $\mathrm{C}^{+}$and $\mathrm{H}^{+}$ions. Sputtering yields $Y_{\mathrm{C}^{+}, \mathrm{H}}$ and $Y_{\mathrm{H}^{+}, \mathrm{H}}$ can be calculated with SRIM. The total sputtering coefficient $\left(\mathrm{s}^{-1}\right)$ would be $Y_{\mathrm{H}}=i_{\mathrm{C}^{+}} Y_{\mathrm{C}^{+}, \mathrm{H}}+i_{\mathrm{H}^{+}} Y_{\mathrm{H}^{+}, \mathrm{H}}$. As a result of sputtering, $\mathrm{H}$ concentration on the surface decreases, and some carbon atoms are activated.

(1) (surface) $-\mathrm{C}_{s p^{2}} \mathrm{H} \rightarrow($ surface $)-\mathrm{C}_{s p^{2}}^{*}$,

(2) (surface) $-\mathrm{C}_{s p^{2}} \mathrm{H}_{2} \rightarrow$ (surface) $-\mathrm{C}_{s p^{2}} \mathrm{H}^{*}$,

(3) (surface) $-\mathrm{C}_{s p^{3}} \mathrm{H} \rightarrow$ (surface) $-\mathrm{C}_{s p^{3}}^{*}$,

(4) (surface) $-\mathrm{C}_{s p^{3}} \mathrm{H}_{2} \rightarrow$ (surface) $-\mathrm{C}_{s p^{3}} \mathrm{H}^{*}$,

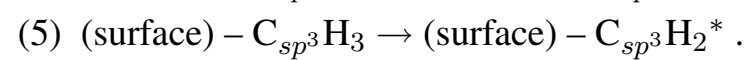

The reaction rate equations for above processes are these:

$$
\begin{gathered}
\left(\frac{\mathrm{d} c_{15}^{(1)}}{\mathrm{d} t}\right)_{\mathrm{H}}=-Y_{\mathrm{H}}\left(c_{5}^{(1)}+c_{7}^{(1)}+c_{10}^{(1)}+c_{12}^{(1)}+c_{14}^{(1)}\right), \\
\left(\frac{\mathrm{d} c_{j}^{(1)}}{\mathrm{d} t}\right)_{j}=-Y_{\mathrm{H}} c_{j}^{(1)},\left(\frac{\mathrm{d} c_{i}^{(1)}}{\mathrm{d} t}\right)_{i}=Y_{\mathrm{H}} c_{j}^{(1)},
\end{gathered}
$$

where $j$ and $i$ are conjugate indices, see Section 2.4.

\subsection{Physical sputtering of $C$ atoms on the surface}

We take that all carbon atoms of any state can be sputtered by carbon ions from the surface. Their concentration on the surface decreases as

$$
\left(\frac{\mathrm{d} c_{j}^{(1)}}{\mathrm{d} t}\right)_{j}=-Y_{0} c_{j}^{(1)},
$$


where $Y_{0}=i_{\mathrm{C}^{+}} Y_{\mathrm{C}^{+}, \mathrm{C}}$ is a coefficient $\left(\mathrm{s}^{-1}\right)$ of $\mathrm{C}$ sputtering with $\mathrm{C}^{+}$ions, $Y_{\mathrm{C}^{+}, \mathrm{C}}$ is a sputtering yield found with SRIM for different ion energies, $j=3, \ldots, 14$ (corresponds to particles $\mathrm{C}_{s p^{2}}, \mathrm{C}_{s p^{2}}^{*}, \mathrm{C}_{s p^{2}} \mathrm{H}, \mathrm{C}_{s p^{2}} \mathrm{H}^{*}$, $\mathrm{C}_{s p^{2}} \mathrm{H}_{2}, \mathrm{C}_{s p^{3}}, \mathrm{C}_{s p^{3}}^{*}, \mathrm{C}_{s p^{3}} \mathrm{H}, \mathrm{C}_{s p^{3}} \mathrm{H}^{*}, \mathrm{C}_{s p^{3}} \mathrm{H}_{2}, \mathrm{C}_{s p^{3}} \mathrm{H}_{2}{ }^{*}$, $\mathrm{C}_{s p^{3}} \mathrm{H}_{3}$, respectively). $\mathrm{H}$ concentration on the surface also decreases because some carbon atoms on the surface are bonded to $\mathrm{H}$ atoms and they are sputtered together,

$$
\begin{aligned}
\left(\frac{\mathrm{d} c_{15}^{(1)}}{\mathrm{d} t}\right)_{\mathrm{H}}=-Y_{0}( & \sum_{j=5,6,10,11} c_{j}^{(1)} \\
& \left.+2 \sum_{j=7,12,13} c_{j}^{(1)}+3 c_{14}^{(1)}\right) .
\end{aligned}
$$

\subsection{Non-equilibrium insertion of atoms into bulk of the film $(k>1)$}

Our model states that $\mathrm{H}$ atoms and ions are inserted into bulk of the film when they add to dangling bonds. $\mathrm{H}$ atoms in the bulk of the film can be abstracted by incident $\mathrm{H}$ atoms or displaced by incident ions (Secs. 2.4 and 2.8). Variation of concentration of $i$ th type particles in $k$ th monolayer due to $\mathrm{H}$ insertion and removal is given by expressions

$$
\begin{aligned}
\left(\frac{\mathrm{d} c_{i}^{(k)}}{\mathrm{d} t}\right)_{i}= & A_{1}^{(k)} c_{i}^{(k+1)}+B_{1}^{(k)} c_{i}^{(k-1)} \\
& -\left(A_{2}^{(k)}+B_{2}^{(k)}\right) c_{i}^{(k)} \\
A_{1}^{(k)}= & \sum_{L=k+1}^{n} A^{(L)}, A_{2}^{(k)}=\sum_{L=k}^{n} A^{(L)}, \\
B_{1}^{(k)}= & \sum_{L=k}^{n} C_{\mathrm{R}}, B_{2}^{(k)}=\sum_{L=k+1}^{n} C_{\mathrm{R}}, \\
A^{(L)}= & k_{\mathrm{H}} i_{\mathrm{H}}^{(L)} \sum_{j=4,6,9,11,13} c_{j}^{(L)}, \\
C_{\mathrm{R}}= & \left(w_{\mathrm{HH}} i_{\mathrm{H}}^{(L)}+G_{\mathrm{H}}^{(L)}\right) \sum_{j=5,7,10,12,14} c_{j}^{(L)} .
\end{aligned}
$$

\subsection{Deposition and sputtering rate}

Film deposition rate $V_{A}$, etching rate $V_{S}$, and the net deposition rate $V$ are presented as Eqs. (27)-(29).

$$
\begin{aligned}
V_{A}= & 4 k_{\mathrm{R}} i_{\mathrm{R}} c_{2}^{(1)}+\left(4 k_{\mathrm{R}} i_{\mathrm{R}}+k_{\mathrm{H}} i_{\mathrm{H}}\right) \sum_{j=4,6,9,11,13} c_{j}^{(1)} \\
& +A_{2}^{(1)}, \\
V_{S}= & \left(w_{\mathrm{HH}} i_{\mathrm{H}}+Y_{\mathrm{H}}\right) \sum_{j=5,7,10,12,14} c_{j}^{(1)}+B_{2}^{(1)} \\
& +Y_{0} \sum_{i=3}^{14} c_{i}^{(1)}+Y_{0}\left(c_{5}^{(1)}+c_{6}^{(1)}+2 c_{7}^{(1)}+c_{10}^{(1)}\right. \\
& \left.+c_{11}^{(1)}+2 c_{12}^{(1)}+2 c_{13}^{(1)}+3 c_{14}^{(1)}\right) \\
V & V_{A}-V_{S} .
\end{aligned}
$$

The final set is composed of $n_{\mathrm{p}} \cdot n_{\mathrm{sl}}$ reaction rate equations of the form $\mathrm{d} c_{i}^{(k)} / \mathrm{d} t=\ldots$, for all particle types $i=1, \ldots, n_{\mathrm{p}}\left(n_{\mathrm{p}}=15\right)$ in every monolayer $k=$ $1, \ldots, n_{\mathrm{sl}}$. They are obtained simply by adding the contribution of all processes described by Eqs. (2)-(29). Note that all sets of equations for the bulk of the film $(k>1)$ will be the same (difference appears only in values of coefficients), so in fact we have only two forms of equation sets: one for the surface $(k=1)$ and one for the bulk $(k>1)$. These $n_{\mathrm{p}} \cdot n_{\mathrm{sl}}$ rate equations are solved all together by computer using any kind of numerical integration algorithm, e. g. Euler's or Runge-Kutta.

\subsection{Mass density of the film}

We can calculate film density $\rho\left(\mathrm{g} / \mathrm{cm}^{3}\right)$ as an average density of all monolayers using final depth profiles of particle concentrations:

$$
\begin{aligned}
\rho & =\frac{1}{n} \sum_{k=1}^{n} \rho^{(k)}=\frac{1}{n} \sum_{k=1}^{n} \frac{m^{(k)}}{V^{(k)}} \\
& =\frac{1}{n} \sum_{k=1}^{n} \frac{\sum_{i=1}^{15} c_{i}^{(k)} M_{i}}{\sum_{i=1}^{15} \frac{c_{i}^{(k)} M_{i}}{\rho_{i}}}
\end{aligned}
$$

where $\rho^{(k)}, V^{(k)}\left(V^{(k)}=\right.$ const $)$, and $m^{(k)}$ are the density, volume, and mass, respectively, of the $k$ th monolayer, $\rho_{i}$ and $M_{i}$ are mass density and atomic mass of 


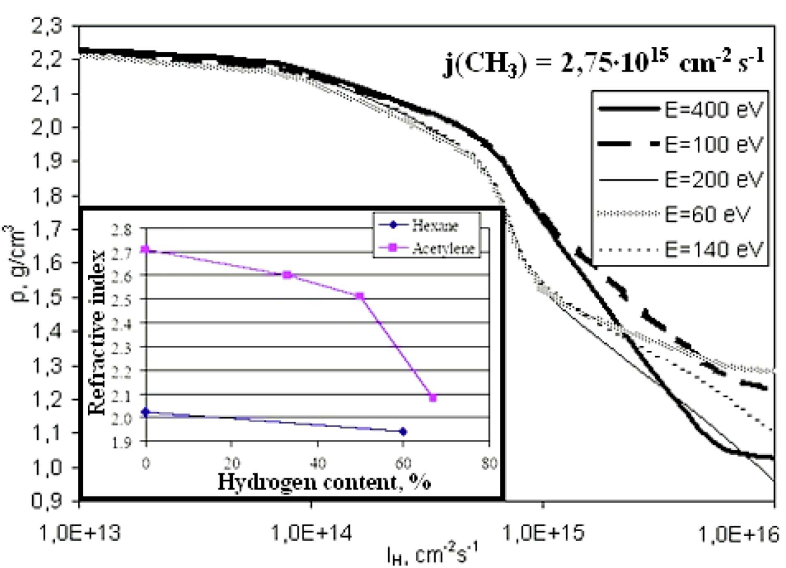

Fig. 1. Calculated a-C:H film density versus $\mathrm{H}$ flux. Inset: refractive index of a-C:H film deposited from various acetylene/hydrogen and hexane/ hydrogen mixtures [19].

$i$ th type species, respectively, $n$ is a number of monolayers.

\section{Results and discussion}

Film growth was simulated for $1000 \mathrm{~s}$ with a time step of $0.1 \mathrm{~s}$ at $300 \mathrm{~K}$. The number of monolayers $n_{\mathrm{sl}}$ was set to $150-200$. Relative flux $i_{\mathrm{C}^{+}}$of $\mathrm{C}^{+}$ions was fixed at $0.1 \mathrm{~s}^{-1}\left(2.75 \cdot 10^{14} \mathrm{~cm}^{-2} \mathrm{~s}^{-1}\right)$, and the ratio $I_{\mathrm{H}} / I_{\mathrm{H}^{+}}$of hydrogen radical-to-ion fluxes was always equal to 9 . Values of some reaction rate coefficients that do not depend on ion energy are presented in Table 2. Fractions $i_{\mathrm{C}^{+}}^{(k)}, i_{\mathrm{H}^{+}}^{(k)}$, and $i_{\mathrm{H}^{\prime}}^{(k)}$ of incident $\mathrm{C}^{+}$ions, $\mathrm{H}^{+}$ions, and $\mathrm{H}$ atoms that penetrate into the film and remain in the $k$ th monolayer are calculated according to Eq. (1). Penetration depths $R_{\mathrm{pC}^{+}}$and $R_{\mathrm{pH}^{+}}$ and standard deviations $\Delta R_{\mathrm{pC}^{+}}$and $\Delta R_{\mathrm{pH}^{+}}$of incident $\mathrm{C}^{+}$and $\mathrm{H}^{+}$ions, respectively, were calculated for every particular ion energy using SRIM 2003 software [17]. $R_{\mathrm{pH}^{\prime}}$ and $\Delta R_{\mathrm{pH}^{\prime}}$ (Table 2) do not depend on ion energy. Coefficients $G_{1 \mathrm{H}}^{(k)}$ and $G_{2 \mathrm{H}}^{(k)}$ for displacement of $\mathrm{H}$ atoms in $k$ th monolayer with incident $\mathrm{C}^{+}$and $\mathrm{H}^{+}$ions depend on ion energy. They were found from depth distribution of $\mathrm{H}$ vacancies (H vacancies/ion/ $/ \AA$ ) with SRIM. We assume that molecular ion completely breaks into atomic ions upon impact with surface. Ion energy hereafter is equivalent to energy per $C$ ion commonly used in experimental plots.

\subsection{Density of the film}

Film deposition rate and density were calculated using Eqs. (29) and (30) as functions of $\mathrm{H}$ flux for various constant incident ion energies (Figs. 1,2). Very low $\mathrm{H}$ flux leads to insignificant film growth [6], so

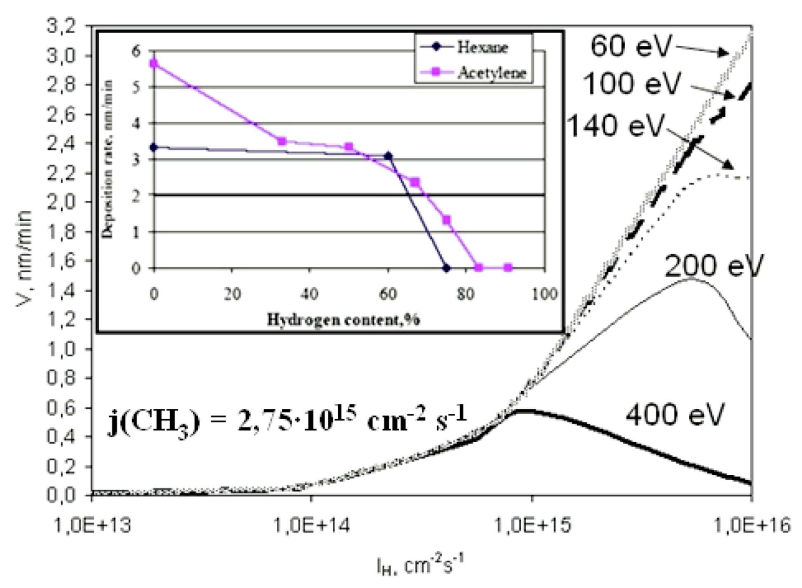

Fig. 2. Calculated deposition rate of a-C:H film versus $\mathrm{H}$ flux density. Inset: deposition rate as a function of $\mathrm{H}$ content in acetylene/hydrogen and hexane/hydrogen gas mixtures [19].

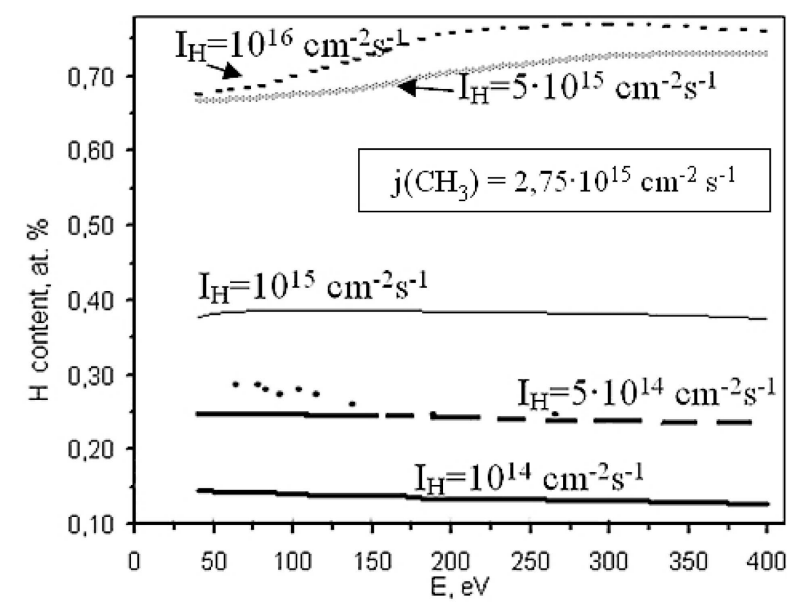

Fig. 3. Experimental (points) [1] and calculated (lines) H content versus ion energy for various $\mathrm{H}$ flux densities.

film density remains close to the density of silicon substrate $\left(2.33 \mathrm{~g} / \mathrm{cm}^{3}\right)$. At high $\mathrm{H}$ fluxes, film density decreases to $\sim 1.5 \mathrm{~g} / \mathrm{cm}^{3}$ (Fig. 1) due to high $\mathrm{H}$ content [6] (Fig. 3).

When $\mathrm{H}$ flux is lower than $5 \cdot 10^{14} \mathrm{~cm}^{-2} \mathrm{~s}^{-1}$, ion energy can barely have any effect on film density, too (Fig. 1). With increasing $\mathrm{H}$ flux, film density remains the highest for ion energies of 100 and $400 \mathrm{eV}$, while experimental dependences [18] have a maximum at bias voltage of 200 or $400 \mathrm{~V}$ ( 80 or $160 \mathrm{eV} / \mathrm{C}$ ion), and Davis' model predicts the peak of $s p^{3}$ phase formation at $100 \mathrm{eV}$. Intersections of energy dependences of film density with each other indicate a combined effect of several factors, mostly graphite-to-diamond transition and graphitization. We also found that film density versus $\mathrm{H}$ flux curve declines more rapidly in case of high $\mathrm{CH}_{3}$ flux $\left(5 \cdot 10^{15}-10^{16} \mathrm{~cm}^{-2} \mathrm{~s}^{-1}\right)$, which brings more hydrogen to the film.

Film density versus $\mathrm{H}$ flux functions in Fig. 1 agree 
Table 2. Various simulation parameters independent of incident ion energy.

\begin{tabular}{cccccccccc}
\hline$B$ & $\rho$ & $\lambda$ & $k_{\mathrm{R}}$ & $k_{\mathrm{H}}$ & $w_{\mathrm{HH}}$ & $F_{1}\left(\mathrm{~s}^{-1}\right)$ & $F_{2}\left(\mathrm{~s}^{-1}\right)$ & $R_{\mathrm{pH}^{\prime}}(\AA)$ & $\Delta R_{\mathrm{pH}^{\prime}}(\AA)$ \\
\hline 0.1 & 0.8 & 3 & 1 & $10^{-4}$ & 0.6 & 0.01 & 0.01 & 6.0 & 3.0 \\
\hline
\end{tabular}

qualitatively with experimental dependence of refractive index $n_{\mathrm{r}}$ on additional hydrogen content in deposition gas mixture $C_{\mathrm{H}}$ in Fig. 1 inset [19]. This is expected because $C_{\mathrm{H}}$ is proportional to $\mathrm{H}$ flux, and relation between $n_{\mathrm{r}}$ and mass density of a-C:H is confirmed by many authors $[1,6,19]$.

\subsection{Deposition rate of a-C:H film}

Deposition rate strongly depends on ion energy via erosion. The lower the ion energy the higher the deposition rate is (Fig. 2). Also, low energy ions do not penetrate as deep in the film so the maximum of ion energy loss profile is closer to the surface. This leads to creation of more DBs on the surface and enhanced hydrocarbon adsorption. Deposition rate strongly depends on $\mathrm{CH}_{3}$ flux (not shown here). However, upon low $\left(<10^{14} \mathrm{~cm}^{-2} \mathrm{~s}^{-1}\right) \mathrm{H}$ fluxes, film growth is slow even if $\mathrm{CH}_{3}$ flux is intense because surface DBs are saturated by $\mathrm{CH}_{3}$ too rapidly. Thus, both $\mathrm{H}$ and $\mathrm{CH}_{3}$ fluxes over $10^{15} \mathrm{~cm}^{-2} \mathrm{~s}^{-1}$ are recommended.

Interestingly, deposition rate varies nonmonotonously, passing a maximum at a certain $\mathrm{H}$ flux density that decreases with ion energy (Fig. 2). In case of lower energies, 140,100 , and $60 \mathrm{eV}$, no deposition rate peaks are observed up to $10^{16} \mathrm{~cm}^{-2} \mathrm{~s}^{-1}$, probably they emerge at $\mathrm{H}$ fluxes higher than $10^{16} \mathrm{~cm}^{-2} \mathrm{~s}^{-1}$.

As mentioned above, decline in deposition rate at high $\mathrm{H}$ fluxes $\left(\sim 10^{16} \mathrm{~cm}^{-2} \mathrm{~s}^{-1}\right.$, Fig. 2$)$ can be associated with a slowdown of $\mathrm{CH}_{3}$ adsorption. The latter greatly affects the $s p^{3}$ content, $\mathrm{H}$ content, and mass density of the film: (i) the $s p^{3}$ content decreases (Fig. 4) because hydrocarbon adsorption is one of the main mechanisms for creation of $s p^{3}$ bonds [13]; (ii) $\mathrm{H}$ content increases until saturation (Fig. 3); (iii) film density decreases until the steady state value (Fig. 1).

In contrast to our results, experimentally measured rate of direct ion beam deposition (DIBD) by Grigonis et al. [19] declines in entire range of $\mathrm{H}$ content in the gas mixture (inset in Fig. 2). The mismatch may appear due to fact that we have excluded etching and sputtering with hydrogen from our model. On the other hand, we have modelled CVD, which employs lower ion fluxes than DIBD. Schwarz-Selinger et al. [6] have found experimentally and, later, by modelling that steady state deposition rate of a-C:H increases with increasing H flux density (Fig. 5). This outcome is con-

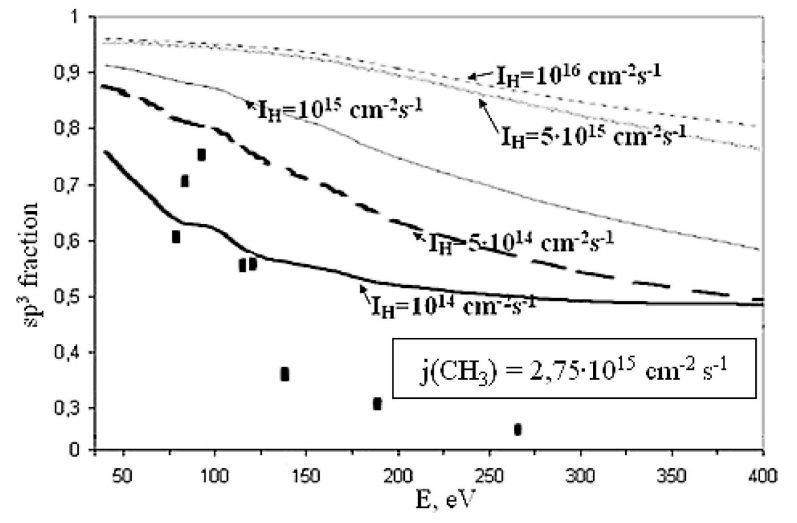

Fig. 4. Experimental (points) [1] and calculated (lines) $s p^{3}$ fraction versus incident ion energy.

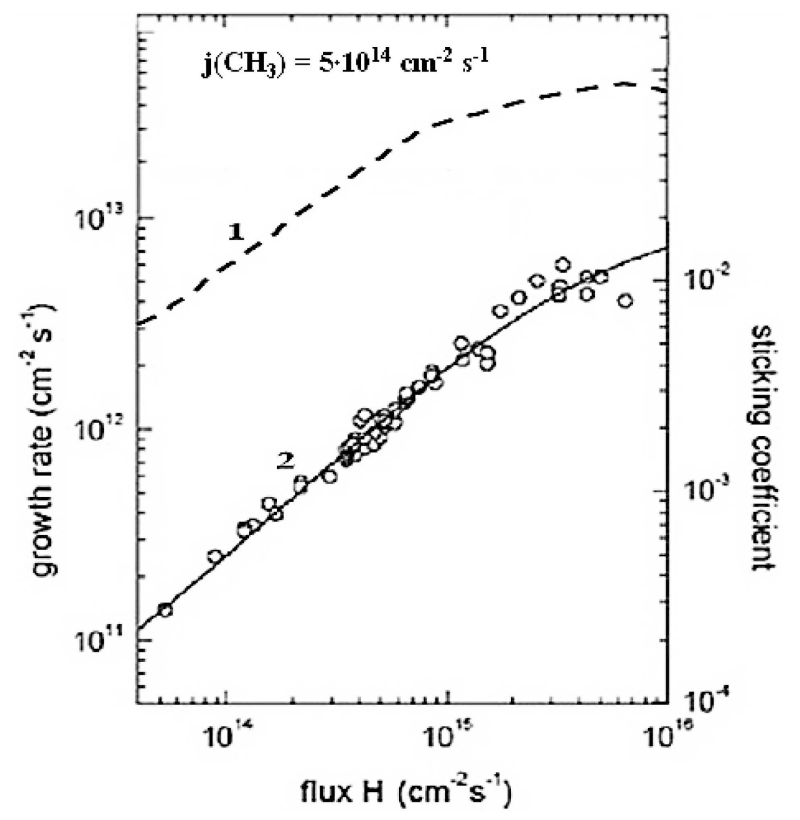

Fig. 5. a-C:H film deposition rate versus atomic hydrogen flux to the surface, with effective sticking coefficients: 1 is a calculated curve (this work), 2 marks experimental points and theoretical curve [6].

sistent with our results though experimental values are one order of magnitude smaller. Effective sticking coefficients on the right axis in Fig. 5 were calculated using film deposition rate $\mathrm{V}$ and $\mathrm{CH}_{3}$ flux: $k_{\mathrm{CH}_{3}} \approx$ $V / I_{\mathrm{CH}_{3}}$. It seems that the rising part of our deposition rate curve in Fig. 2 matches that of Schwarz-Selinger, while the decreasing part corresponds to findings of Grigonis et al.

Let us analyse how $\mathrm{H}$ flux affects film deposition rate if ion bombardment and relaxation of DBs are 
neglected. When $\mathrm{CH}_{3}$ flux density is constant, deposition rate depends on etching rate and steady state concentration of surface DBs because hydrocarbon radicals, which are main deposited species, are adsorbed mostly on DBs.

1. In case of low $\mathrm{H}$ flux, incident $\mathrm{H}$ atoms abstract few surface-bonded $\mathrm{H}$ atoms and create few DBs, in comparison with $\mathrm{CH}_{3}$ adsorption rate, so the steady state concentration of surface DBs is low. Consequently, film deposition (i.e. $\mathrm{CH}_{3}$ adsorption) rate is low, too.

2. DB creation speeds up with increasing $H$ flux. Although adsorption of $\mathrm{H}$ atoms and $\mathrm{CH}_{3}$ radicals on the surface is then greatly enhanced, the steady state concentration of surface DBs slowly increases with $\mathrm{H}$ flux density and film deposition rate increases as well.

3. After $\mathrm{H}$ flux far surpasses $\mathrm{CH}_{3}$ flux, $\mathrm{CH}_{3}$ adsorption effect on surface concentration of $\mathrm{H}$ and DBs becomes insignificant. The steady state surface concentration of $\mathrm{H}$ atoms is then directly proportional to $\mathrm{H}$ adsorption rate, and DB surface concentration is proportional to abstraction rate of surface bonded $\mathrm{H}$ by incoming $\mathrm{H}$. In other words, the concentration ratio of $\mathrm{H}$ atoms / DBs on the surface is approximately equal to the ratio of $\mathrm{H}$ adsorption/abstraction rates. DB concentration $c_{\mathrm{DB}}$ depends only on $\mathrm{H}$ adsorption and abstraction probabilities $k_{\mathrm{H}}$ and $w_{\mathrm{HH}}\left(\mathrm{s}^{-1}\right)$, respectively, $c_{\mathrm{DB}} \sim$ $w_{\mathrm{HH}} /\left(w_{\mathrm{HH}}+k_{\mathrm{H}}\right)$.

4. Upon further enhanced $\mathrm{H}$ fluxes, $c_{\mathrm{DB}}$ concentration becomes nearly constant because the rate of surface DB creation approaches rate of DB recombination. However, film deposition rate declines because etching becomes crucial at high $\mathrm{H}$ fluxes.

\section{3. $s p^{3} / s p^{2}$ ratio}

We deduced the $s p^{3} / s p^{2}$ ratio or the $s p^{3}$ content from the final film composition. The $s p^{3}$ content decreases from $88 \%$ at $40 \mathrm{eV}$ down to $55 \%$ at $300 \mathrm{eV}$ while experimental $s p^{3}$ content drops from 80 to $20 \%$ in the range of $100-300 \mathrm{eV}$ (Fig. 4). It is known that decrease in $s p^{3}$ content is caused mainly by diamond-tographite transition (graphitization) induced by high energy ions. Experimental dependences of $s p^{3}$ bond fraction on ion energy have a maximum at $100 \mathrm{eV}[1,14]$ or at $160 \mathrm{eV}$ [20]. Graphite transition to hexagonal diamond was also included in our model but only a small local maximum is visible in calculated $s p^{3}$ curves at
$100 \mathrm{eV}$ (Fig. 4) instead of dominating peak claimed by Davis. Moreover, in low-energy range where no graphitization is present, $s p^{3}$ content depends on $\mathrm{H}$ flux more than at high ion energies. This is an indication that $s p^{3}$ bond formation occurs predominantly by rapid hydrocarbon adsorption on the surface but not via $s p^{2} \rightarrow s p^{3}$ transition in the bulk, induced by ion implantation. Molecular dynamics study performed by Marks et al. [13] has proved that $s p^{3}$ bond formation via adsorption is also substantial in tetrahedral amorphous carbon (ta-C) growth. It seems that at high energies the $s p^{3}$ content also increases mainly due to hydrocarbon adsorption, and in the bulk it is reduced by graphitization.

The fact that not only $\mathrm{C}-\mathrm{C} s p^{3}$ bonds but $\mathrm{C}-\mathrm{H} s p^{3}$ bonds as well contribute to $s p^{3}$ curve in Fig. 4 may be worth noting. The $s p^{3}$ content increases rapidly with increasing $\mathrm{H}$ flux because $\mathrm{CH}_{3}$ adsorption gets faster, and more $s p^{3}$ bonds are formed; also, larger $\mathrm{H}$ content in the film stabilizes more $s p^{3}$ bonds. Saturation of $s p^{3} / s p^{2}$ ratio at high $\mathrm{H}$ flux could be explained by slowdown in $s p^{3}$ bond creation and not by graphitization, which most likely does not vary much with $\mathrm{H}$ flux. This applies to higher energy range of $200-400 \mathrm{eV}$ at first. Such ions induce intense graphitization and produce more DB, the relaxation of which leads to formation of $s p^{2} \mathrm{C}=\mathrm{C}$ bonds. Experimental [1] and calculated dependences of $\mathrm{H}$ content on incident ion energy in Fig. 3 are qualitatively similar. Note that ion energy does not have much effect on the total $\mathrm{H}$ content in the film but it obviously affects $\mathrm{H}$ concentration on the surface.

\section{Conclusions}

1. The dependence of atomic hydrogen flux on deposition rate has a clear peak, which is in agreement with experimental results. Deposition rate declines at high $\mathrm{H}$ fluxes because dangling bond concentration does not increase any more and etching becomes crucial.

2. $\mathrm{C}-\mathrm{C} s p^{3}$ bonds are created mainly by hydrocarbon adsorption on the surface and not by stress that originates from ion bombardment. However, $s p^{3}$ fraction decreases mostly due to graphitization induced by ion bombardment.

3. The total $\mathrm{H}$ content in the film, in contrast to $\mathrm{H}$ concentration on the surface, depends only slightly on incident ion energy. 
4. The $s p^{3} / s p^{2}$ ratio and mass density of the film depend on deposition rate.

\section{Acknowledgement}

This work was supported by the Lithuanian State Science and Studies Foundation.

\section{References}

[1] J. Robertson, Mater. Sci. Eng. R 37, 129-281 (2002).

[2] Y. Lifshitz, S.R. Kasi, and J.W. Rabalais, Phys. Rev. Lett. 62(11), 1290-1293 (1989).

[3] C.A. Davis, Thin Solid Films 226, 30-34 (1993).

[4] D.R. McKenzie, Rep. Prog. Phys. 59, 1611-1664 (1996).

[5] A. von Keudell, M. Meier, and C. Hopf, Diamond Related Mater. 11, 969-975 (2002).

[6] T. Schwarz-Selinger, M. Meier, C. Hopf, A. von Keudell, and W. Jacob, Vacuum 71, 361-376 (2003).

[7] J. Küppers, Surf. Sci. Rep. 22, 249-321 (1995).

[8] S.-Tong Lee, Mater. Sci. Eng. R 25, 123-154 (1999).
[9] J. Robertson, Diamond Related Mater. 12, 79-84 (2003).

[10] M. Bilek and D.R. McKenzie, Surf. Coat. Technol. 10, 4345-4354 (2006).

[11] A. von Keudell, Thin Solid Films 402, 1-37 (2002).

[12] W. Jacob, J. Nucl. Mater. 337-339, 839-846 (2005).

[13] N.A. Marks, D.R. McKenzie, and B.A. Pailthorpe, Phys. Rev. B 53(7), 4117-4124 (1996).

[14] H.X. Li, T. Xu, J.M. Chen, H.D. Zhou, and H.W. Liu, Appl. Surf. Sci. 227(1-4), 364-372 (2004).

[15] G.W. Yang and B.X. Liu, Diamond Related Mater. 9, 156-161 (2000).

[16] W. Jacob, C. Hopf, and M. Schlüter, Phys. Scripta T124, 32-34 (2005).

[17] J. Ziegler, SRIM \& TRIM (2004), http: / / www.srim.org.

[18] J. Robertson, Diamond Related Mater. 3(4-6), 361368 (1994).

[19] A. Grigonis, V. Šablinskas, M. Šilinskas, and D. Tribandis, Vacuum 75, 261-267 (2004).

[20] O. Durand-Drouhin, M. Lejeune, R. Bouzerar, and M. Benlahsen, Mater. Sci. Semicond. Processing 4, 213-215 (2001).

\title{
a-C:H DANGU CHEMINIO NUSODINIMO IŠ GARU FAZĖS ANT Si PADE்KLO KINETIKOS MODELIAVIMAS
}

\author{
A. Ibenskas ${ }^{\text {a }}$, A. Galdikas ${ }^{\text {a, b }}$, A. Grigonis ${ }^{a}$ \\ ${ }^{\text {a }}$ Kauno technologijos universitetas, Kaunas, Lietuva \\ ${ }^{\mathrm{b}}$ Kauno medicinos universitetas, Kaunas, Lietuva
}

\section{Santrauka}

Siūlomas naujas reakcijų greičiu lygčių modelis, aprašantis a-C:H dangų chemini nusodinimą iš garu fazès (chemical vapour deposition, CVD). Apskaičiuojamos dangos augimo greičio ir dangos tankio priklausomybès nuo vandenilio atomų srauto i paviršių, esant skirtingiems $\mathrm{CH}_{3}$ radikalų srauto tankiams ir skirtingoms jonu energijoms, kokybiškai sutampa su eksperimentų rezultatais. Manoma, kad dangos augimo greičio priklausomybè nuo vandenilio srauto turi maksimumą dèl to, kad laisvų ryšių koncentracija, lemianti $\mathrm{CH}_{3}$ adsorbciją, nustoja didèti, o ėsdinimas stipreja.
Skaičiavimu ir eksperimentų rezultatai rodo, kad vandenilio kiekis dangoje beveik nepriklauso nuo jonu energijos. Išanalizavus apskaičiuotas $s p^{3} / s p^{2}$ santykio ir vandenilio kiekio priklausomybes nuo jonu energijos, esant skirtingiems $\mathrm{H}$ srautams, padarytos dvi svarbios išvados. Pirmiausia, pagrindinis $s p^{3}$ ryšiu susidarymo mechanizmas gali būti angliavandenilių adsorbcija ant paviršiaus, o ne įtempiai dangos tūryje (subplantacijos mechanizmas). Tai sutampa su kitu autorių modeliavimo rezultatais. Antra, pagrindinis $s p^{3}$ ryšiu suirimo mechanizmas - grafitizacija, vykstanti šiluminèse smailèse, kurias sukuria dangą bombarduojantys jonai. 